\title{
Removal of Mercury from SBW Vitrification Off-Gas by Activated Carbon
}

\author{
J. A. Del Debbio \\ T. T. Watson \\ R. J. Kirkham
}

September 2001

Idaho National Engineering and Environmental Laboratory Bechtel BWXT Idaho, LLC 


\title{
Removal of Mercury from SBW Vitrification Off-Gas by Activated Carbon
}

\author{
J. A. Del Debbio \\ T. T. Watson \\ R. J. Kirkham
}

September 2001

Idaho National Engineering and Environmental Laboratory Idaho Falls, Idaho 83415

Prepared for the

U.S. Department of Energy

Assistant Secretary for Environmental Management

Under DOE Idaho Operations Office

Contract DE-AC07-99ID13727 


\section{SUMMARY}

Radioactive, acidic waste stored at the Idaho Nuclear Technology and Engineering Center (INTEC) have been previously converted into a dry, granular solid at the New Waste Calcining Facility (NWCF). As an alternative to calcination, direct vitrification of the waste, as well as the calcined solids in an Idaho Waste Vitrification Facility (IWVF) is being considered to prepare the waste for final disposal in a federal repository. The remaining waste to be processed is Sodium-Bearing Waste (SBW).

Off-gas monitoring during NWCF operations have indicated that future mercury emissions may exceed the proposed Maximum Achievable Control Technology (MACT) limit of $130 \mathrm{ug} / \mathrm{dscm}$ (micrograms/dry standard cubic meter)@ 7\% $\mathrm{O}_{2}$ for existing Hazardous Waste Combustors (HWC) if modifications are not made. Carbon monoxide and hydrocarbon emissions may also exceed the MACT limits. Off-gas models have predicted that mercury levels in the off-gas from SBW vitrification will exceed the proposed MACT limit of $45 \mathrm{ug} / \mathrm{dscm} @ 7 \% \mathrm{O}_{2}$ for new HWCs.

Options to enable the NWCF to meet the MACT limits included construction of a MACT Compliance Facility (MCF), including a Noxidizer for $\mathrm{NO}_{\mathrm{x}}$ removal, or upgrading the NWCF by installing a multi-sieved wet scrubber for mercury removal. Both options included continuous removal of mercury from the scrubber blowdown by electrochemical reduction, followed by an activated carbon polishing bed. In the NWCF upgrade option, the carbon bed was also to be used for removal of products of incomplete combustion. Thus, studies of the mercury removal efficiency of activated carbon were initiated to support the above-mentioned options. These studies indicated that Mersorb ${ }^{\circledR}$, a sulfur-impregnated carbon manufactured by Nucon International, was highly effective ( $>99 \%$ removal) in removing both elemental $\left(\mathrm{Hg}^{\circ}\right)$ and mercuric chloride $\left(\mathrm{HgCl}_{2}\right)$, from test gases containing $1 \% \mathrm{NO}_{2} / 28 \% \mathrm{H}_{2} \mathrm{O}$ and $800 \mathrm{ppmv}$ $\mathrm{NO}_{2} / 44 \% \mathrm{H}_{2} \mathrm{O}$.

Because of its effectiveness in removing both $\mathrm{HgCl}_{2}$ and $\mathrm{Hg}^{\circ}$, and its high sorption capacity for $\mathrm{Hg}^{\circ}\left(20 \mathrm{wt} \%\right.$ according to the vendor), Mersorb ${ }^{\circledR}$ was selected for testing with simulated SBW vitrification off-gas. Removal efficiencies obtained for $\mathrm{HgCl}_{2}$ and $\mathrm{Hg}^{\circ}$ were greater than $99 \%$ in a test gas composed of $46 \% \mathrm{H}_{2} \mathrm{O}, 3.9 \% \mathrm{CO}_{2}, 3.7 \% \mathrm{O}_{2}, 1400$ ppmv $\mathrm{N}_{2} \mathrm{O}, 990$ ppmv NO, 97 ppmv $\mathrm{NO}_{2}, 100$ ppmv CO, 98 ppmv $\mathrm{SO}_{2}$ and 21 ppmv $\mathrm{HCl}$. The balance was $\mathrm{N}_{2}$. Packed carbon beds were used for the tests. The bed weights used were $0.260 \mathrm{~g}$ for test gases containing $\mathrm{HgCl}_{2}$ and $0.199 \mathrm{~g}$ for test gases containing $\mathrm{Hg}^{\circ}$. The carbon was maintained at $90^{\circ} \mathrm{C}$ and gas residence times in the beds were $0.14 \mathrm{~s}$ for $\mathrm{HgCl}_{2}$ and $0.11 \mathrm{~s}$ for $\mathrm{Hg}^{\mathrm{o}}$. $\mathrm{HgCl}_{2}$ test concentrations for two14 hour 
runs were 890 and $770 \mathrm{ug} / \mathrm{m}^{3}$. The $\mathrm{Hg}^{\mathrm{o}}$ concentration for one 16 hour run was $490 \mathrm{ug} / \mathrm{m}^{3}$.

The test results obtained indicated that Mersorb ${ }^{\circledR}$ may have potential for removing a sufficient amount of mercury from SBW vitrification off-gas to enable compliance with the MACT limit. No negative short-term effects of test gas components on mercury removal efficiency were apparent. Future recommended studies include small bed $(1 \mathrm{~cm}$. diameter) tests to determine long-term effects of SBW vitrification off-gas components on $\mathrm{HgCl}_{2}$ and $\mathrm{Hg}^{\circ}$ removal efficiency. Also recommended are breakthrough capacity and bed size optimization studies with a larger test bed to determine maximum removal efficiency, and obtain scale-up data, which can be used to design a carbon adsorption bed for a pilot-scale melter. 


\section{ACKNOWLEDGMENTS}

The authors wish to acknowledge Dr. Larry G. Blackwood for assistance in interpreting statistical data and for derivation of expressions of propagation of error.

The authors also wish to acknowledge Natasia Diers of the INEEL word processing group for formatting and final preparation of this report for publishing. 


\section{CONTENTS}

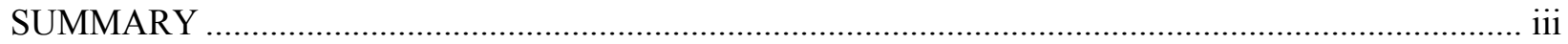

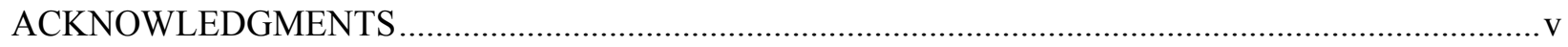

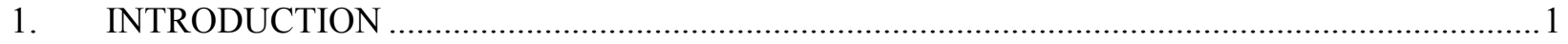

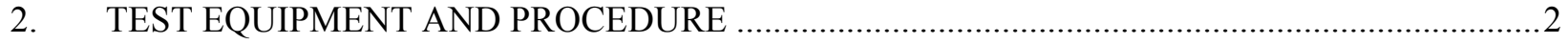

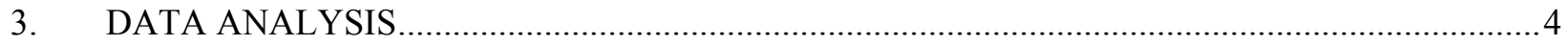

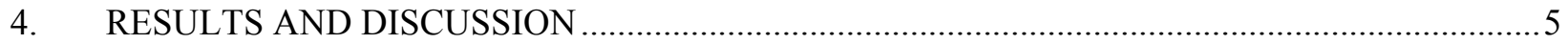

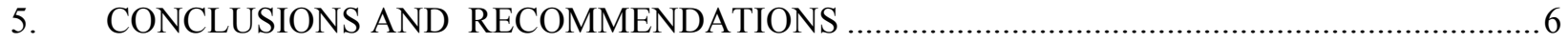

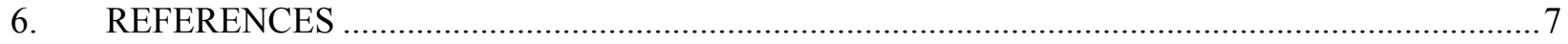

\section{FIGURES}

1. Apparatus for testing activated carbon for removal of mercury from SBW vitrification off-gas. ........... 3

2. Calibration plot for PS Analytical mercury analyzer. .................................................................

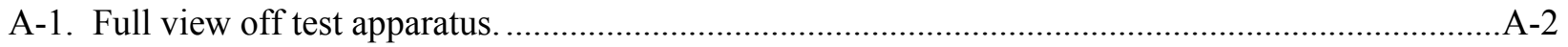

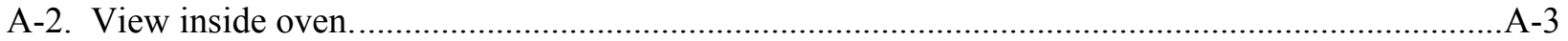

A-3. View of impingers containing $\mathrm{SnCl}_{2} / \mathrm{NaOH}$ solution. ..............................................................

\section{TABLES}

1. Test gas composition and estimates from SBW baseline flow sheets .................................................

2. Removal efficiencies of Mersorb $\AA$ for mercuric chloride and elemental mercury ...............................5 


\section{Removal of Mercury From SBW Vitrification Off-Gas by Activated Carbon}

\section{INTRODUCTION}

From 1982 to 2000, the New Waste Calcining Facility (NWCF) at the Idaho Nuclear Technology and Engineering Center (INTEC) converted acidic, radioactive waste, generated by defense fuel reprocessing, into a granular solid for safe storage. The presence of mercury in the waste is due to its use as a catalyst for the dissolution of aluminum-clad fuel. Off-gas measurements of the fluidized bed calcination process during the processing of Sodium-Bearing Waste (SBW) indicated that mercury emissions exceeded the proposed Maximum Achievable Control Technology Limit (MACT) limit of 130 ug/dscm@7\% $\mathrm{O}_{2}$ for existing Hazardous Waste Combustors (HWC) promulgated by the Environmental Protection Agency (EPA) in July, 1999 $9^{1,2}$. In anticipation of the MACT rule being applied to the NWCF for mercury and other emissions, feasibility studies were conducted to assess off-gas treatment technologies for MACT compliance ${ }^{3,4}$ Flow sheets called for the use of an activated carbon bed to remove both elemental $\left(\mathrm{Hg}^{\circ}\right)$ and oxidized $\left(\mathrm{HgCl}_{2}, \mathrm{HgO}\right)$ forms of mercury. Tests conducted to support these flow sheets indicated that activated carbon was effective in removing $99 \%$ of both $\mathrm{HgCl}_{2}$ and $\mathrm{Hg}^{\mathrm{o}}$ from off-gas simulants containing high levels of $\mathrm{NO}_{2}(1 \%)$ and $\mathrm{H}_{2} \mathrm{O}(44 \%)^{5,6}$. Due to a lack of vapor pressure data and uncertainty as to its stability in the vapor phase, $\mathrm{HgO}$ was not tested. If $\mathrm{HgO}$ is present in SBW vitrification off-gas, it would be expected to be removed by the acid scrubber by dissolution, or by virtue of its being a particulate. By contrast, $\mathrm{HgCl}_{2}$ does not ionize and would have a significant vapor pressure in the off-gas. This was demonstrated in recent $\mathrm{HgCl}_{2}$ vapor/liquid equilibrium studies ${ }^{7}$.

As an alternative to upgrading the NWCF to comply with the MACT rules, an Idaho Waste Vitrification Facility (IWVF) which will immobilize both the SBW and the calcined solids has been proposed and flow sheets have been developed ${ }^{8}$. This facility may be required to comply with the MACT rules or mitigate emissions to As Low As Reasonably Achievable (ALARA) standards. If the MACT rules are applied, mercury emissions will not be allowed to exceed 45ug/dscm @ 7\% $\mathrm{O}_{2}{ }^{2}$. Thus, the studies to evaluate activated carbon for mercury removal conducted to support upgrading the NWCF were extended to support flow sheets developed for the IWVF.

The objective of the studies described in this report was to determine the effects of SBW vitrification off-gas components on the mercury removal efficiency of Mersorb ${ }^{\circledR}$, a sulfur-impregnated activated carbon. The test results were compared with those obtained with a baseline test gas containing air and water vapor. Hence, the tests were designed to determine whether there were any negative shortterm effects of test gas components on mercury removal efficiency. Mersorb $®$ was selected because it was found to be highly effective (>99\% removal) in removing $\mathrm{HgCl}_{2}$ and $\mathrm{Hg}^{\circ}$ from NWCF off-gas simulants ${ }^{5,6}$.

The test gas composition was chosen based on off-gas measurements at the film cooler outlet taken during the melter run with WM 180 surrogate at Clemson University in April, 2001 ${ }^{9}$, and on estimates of de-mister off-gas listed in the Feasibility Study for Vitrification of Sodium-Bearing Waste ${ }^{10}$. 


\section{TEST EQUIPMENT AND PROCEDURE}

The test apparatus used for the determination of mercury removal efficiencies is illustrated in Figure 1. Pictures of the test apparatus can be found in Appendix A. The test gas mixture was produced by the use of commercial calibration gases certified to $\pm 2 \%$ accuracy. The test gas composition and estimates from the SBW vitrification baseline flow sheet ${ }^{8}$ are listed in Table 1 . The flow rates of all gases were controlled by mass flow controllers having an accuracy of $\pm 2 \%$ of full scale. Water vapor was introduced by passing air through a water column whose temperature was controlled by a constant temperature bath. Test gases contained either $\mathrm{HgCl}_{2} \mathrm{Or} \mathrm{Hg}^{\circ}$. These vapors were generated by passing $\mathrm{N}_{2}$ through a packed bed of $\mathrm{HgCl}_{2}$ or over a pool of $\mathrm{Hg}^{\mathrm{o}}$ in a vessel whose temperature was controlled by a constant temperature bath. Downstream of the mixing chamber, the mercury concentration in the test gas was measured by passing it through an impinger containing $2 \% \mathrm{SnCl}_{2} / 5 \% \mathrm{NaOH}$ where $\mathrm{HgCl}_{2}$ was reduced to $\mathrm{Hg}^{\mathrm{O}}$ which was purged into the condenser and into the analyzer which measures only $\mathrm{Hg}^{\mathrm{o}}$. The $\mathrm{NaOH}$ was used to remove acid gases to assure that mercury remained in the reduced state, and to protect the analyzer. By means of valves, the activated carbon bed was bypassed until a stable mercury concentration was reached, at which time the test gas was directed through the carbon bed. Mercury concentrations downstream of the carbon bed were continuously monitored. Prior to terminating a run, the carbon bed was bypassed to re-measure the mercury concentration in the test gas. Mercury concentrations in the test gas near the end of a run tended to be about $90 \%$ of initial concentrations. This may have been caused by signal drift or by changes in equilibrium conditions during the course of the run. This was not unusual considering the tendency of mercury and mercury compounds, particularly $\mathrm{HgCl}_{2}$, to adsorb onto surfaces. Mercury feed concentrations to the carbon bed during a run were taken to be the mean of initial and final concentrations. The carbon bed temperature was maintained at $90^{\circ} \mathrm{C}$. The test gas flow rate through the carbon bed was $220 \mathrm{cc} / \mathrm{min}$.

The PS Analytical Sir Gallahad mercury analyzer was used for the tests. The analyzer was calibrated using a mercury vapor injection system supplied by the vendor. This system consisted of a vessel containing liquid mercury from which measured volumes of mercury-saturated air, at a measured temperature were withdrawn by hypodermic syringe and injected into an $\mathrm{N}_{2}$ carrier gas by means of a sample port. The analyzer software calculated the mass of mercury injected for each injection and developed a calibration curve relating the mass of mercury injected to the signal obtained. The calibration curve used in the tests is shown in Figure 2. The analyzer measured the concentration of mercury in the test gas by pumping a measured sample volume of the gas through a bed of gold-coated sand for a specified time interval. The $\mathrm{Hg}^{\mathrm{o}}$ formed an amalgam with the gold. The gold-coated sand was then heated and purged with $\mathrm{N}_{2}$ to release the mercury into an atomic fluorescence cell for measurement. The mass of mercury measured was converted to a concentration by dividing by the measured sample volume. 


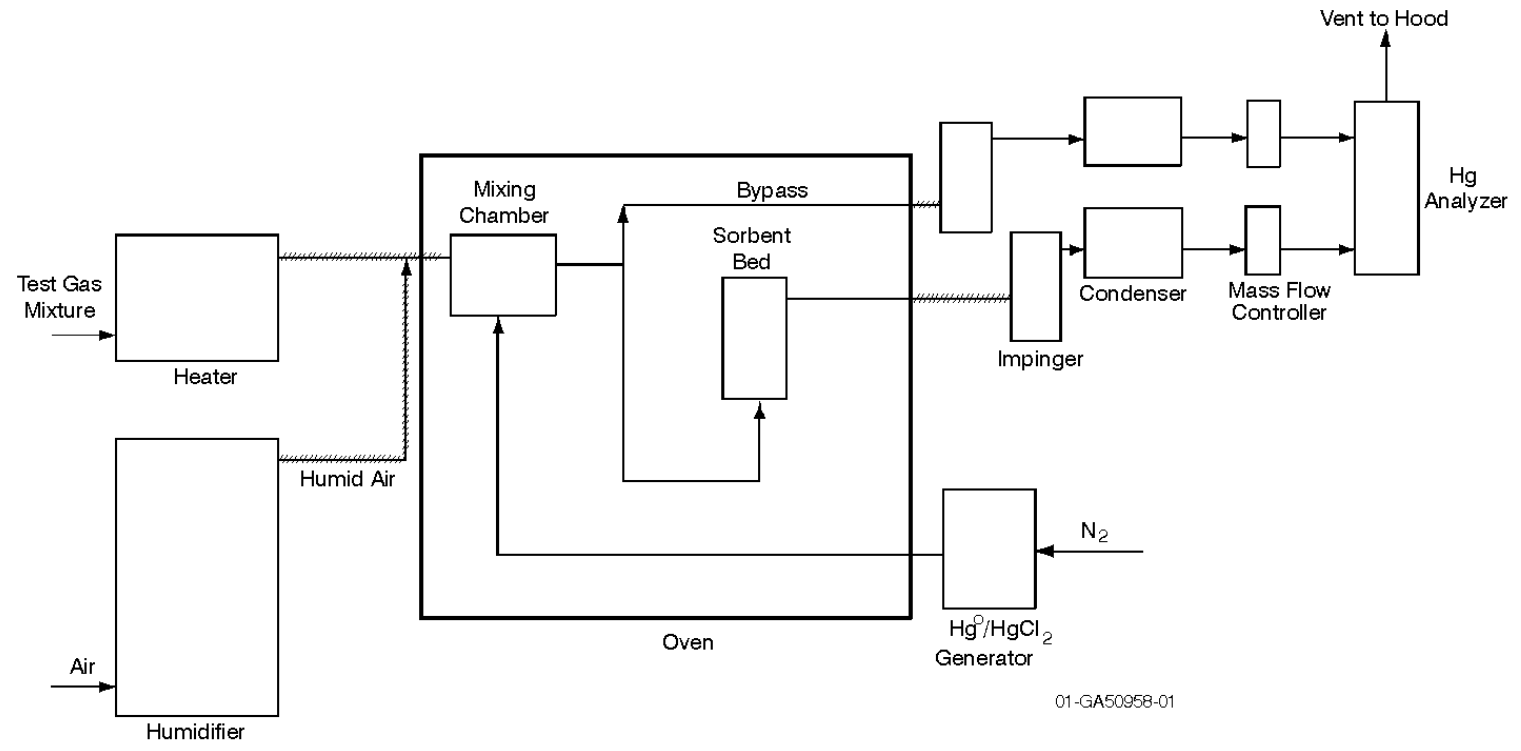

Figure 1. Apparatus for testing activated carbon for removal of mercury from SBW vitrification off-gas.

Table 1. Test gas composition and estimates from SBW baseline vitrification flow sheet.

\begin{tabular}{|c|c|c|}
\hline Component & Test Gas Composition & SBW Baseline Flow Sheet* \\
\hline $\mathrm{N}_{2}$ & $39 \%$ & $39 \%$ \\
\hline $\mathrm{H}_{2} \mathrm{O}$ & $46 \%$ & $52 \%$ \\
\hline $\mathrm{CO}_{2}$ & $3.9 \%$ & $7.6 \%$ \\
\hline $\mathrm{O}_{2}$ & $3.7 \%$ & $0.96 \%$ \\
\hline $\mathrm{N}_{2} \mathrm{O}$ & $0.14 \%$ & None listed \\
\hline $\mathrm{NO}$ & $990 \mathrm{ppmv}$ & $550 \mathrm{ppmv}$ \\
\hline $\mathrm{CO}$ & $100 \mathrm{ppmv}$ & $1.2 \mathrm{ppmv}$ \\
\hline $\mathrm{SO}$ & $98 \mathrm{ppmv}$ & $0.22 \mathrm{ppmv}$ \\
\hline $\mathrm{NO}_{2}$ & $97 \mathrm{ppmv}$ & $0.0066 \mathrm{ppmv}$ \\
\hline $\mathrm{HCl}$ & $21 \mathrm{ppmv}$ & $0.025 \mathrm{ppmv}$ \\
\hline
\end{tabular}

* Estimated composition immediately upstream of Granulated Activated Carbon (GAC) bed ${ }^{8}$ 


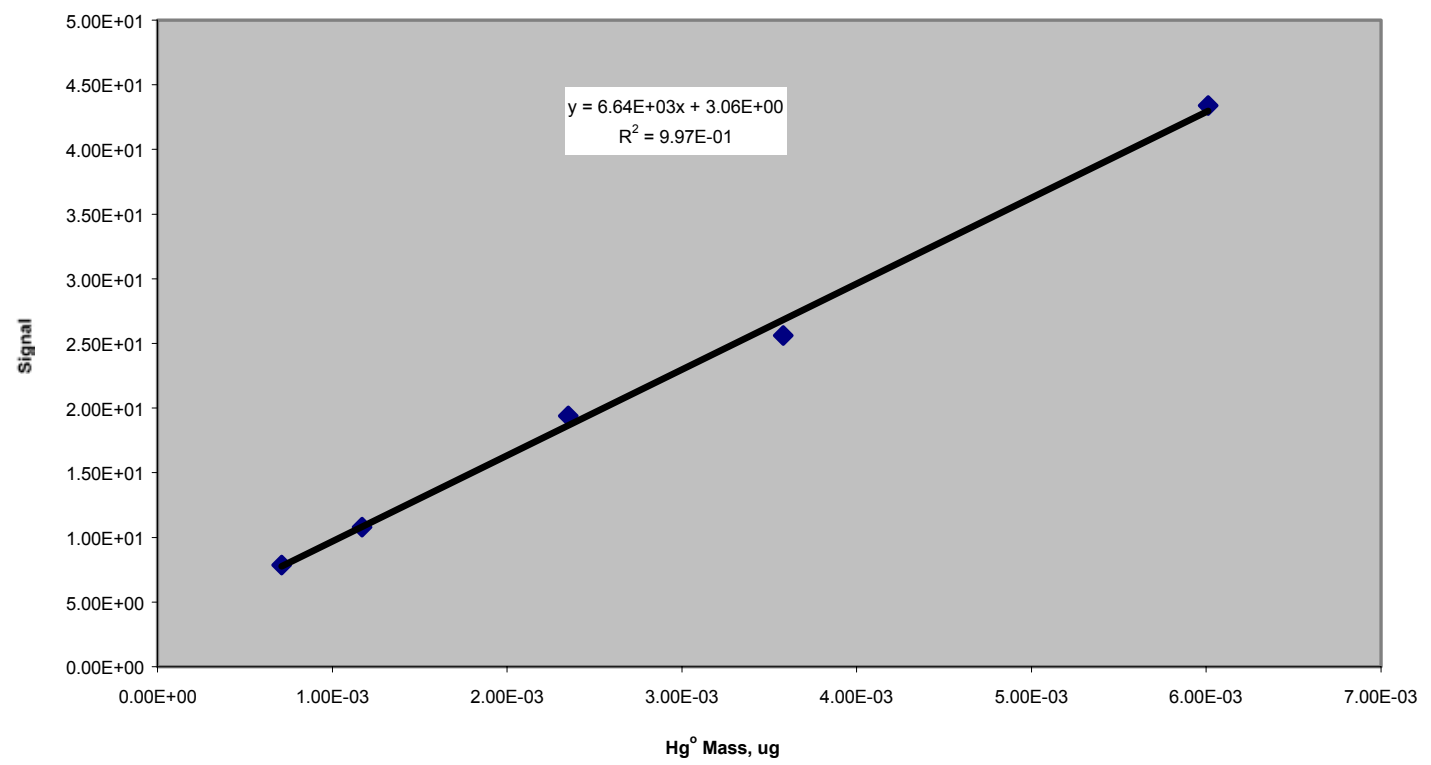

Figure 2. Calibration plot for PS Analytical mercury analyzer.

\section{DATA ANALYSIS}

The mercury removal efficiency of Mersorb ${ }^{\circledR}$ was determined by the following equation:

$\% \mathrm{RE}=\left(\left(\mathrm{C}_{1}-\mathrm{C}_{2}\right) / \mathrm{C}_{1}\right) 100$

Equation 1

where,

$\% \mathrm{RE}=$ Percent removal efficiency

$\mathrm{C}_{1}=$ Mean $\mathrm{HgCl}_{2}$ or $\mathrm{Hg}^{\mathrm{o}}$ concentration upstream of the carbon bed, $\mathrm{ug} / \mathrm{m}^{3}$

$\mathrm{C}_{2}=$ Mean $\mathrm{HgCl}_{2}$ or $\mathrm{Hg}^{\circ}$ concentration downstream of the carbon bed, $\mathrm{ug} / \mathrm{m}^{3}$

Uncertainties in the removal efficiencies were determined by propagating the standard deviations for $C_{1}$ and $C_{2}$ through Equation 1 which resulted in the following equation ${ }^{11}$ :

$$
\sigma_{\% \mathrm{RE}}=100 \sqrt{\left(\frac{\mathrm{C}_{2}}{\mathrm{C}_{1}^{2}}\right)^{2} \sigma_{\mathrm{C}_{1}}^{2}+\left(\frac{1}{\mathrm{C}_{1}}\right)^{2} \sigma_{\mathrm{C}_{2}}^{2}}
$$

where,

$\sigma_{\% \mathrm{RE}}=$ Uncertainty expressed as one standard deviation

$\sigma c_{1}=$ Standard deviation of $\mathrm{C}_{1}$ measurements

$\sigma c_{2}=$ Standard deviation of $\mathrm{C}_{2}$ measurements

Means and standard deviations for $\mathrm{C}_{1}$ and $\mathrm{C}_{2}$ were determined by use of the Excel ${ }^{\circledR}$ statistics program. Derivation of Equation 2 can be found in Appendix B. 


\section{RESULTS AND DISCUSSION}

The removal efficiencies for $\mathrm{HgCl}_{2}$ and $\mathrm{Hg}^{\circ}$ obtained with Mersorb ${ }^{\circledR}$ are listed in Table 2 . Removal efficiencies were greater then $99 \%$ within the indicated uncertainties for both the baseline and the simulated SBW vitrification off-gas compositions. There were no apparent short-term effects on removal efficiencies from test gas components compared to the baseline gas, which was air and water. Long run times and shallow beds were used in an attempt to reach breakthrough. However, it is apparent that larger mercury concentrations or much longer run times will be required in order to reach breakthrough.

Removal efficiencies were high with very short (0.1-0.14s) residence times, and in the presence of a high $(46 \%)$ water content. This indicates that the large surface area available for adsorption of $\mathrm{HgCl}_{2}$ and for reaction of $\mathrm{Hg}^{\mathrm{o}}$ with $\mathrm{S}$, resulted in rapid removal rates, and allowed for co-adsorption of water without immediate effects on mercury sorption. The carbon bed temperature of $90^{\circ} \mathrm{C}$ may have limited the amount of water adsorption thus keeping more sites available for mercury sorption. However, only long-term breakthrough studies will determine the effect of water and other components on breakthrough sorption capacity.

Because of the very shallow carbon beds used for the tests, a 1-2 mm carbon particle size was used in order to reduce channelling effects. A 3-4 $\mathrm{mm}$ particle size is normally recommended by vendors for full-scale application.

Table 2. Removal efficiencies of Mersorb $®$ for mercuric chloride and elemental mercury.

\begin{tabular}{|l|l|c|c|c|c|c|c|c|}
\hline Test \# & \multicolumn{1}{|c|}{ Run } & $\begin{array}{c}\text { Run } \\
\text { Time, } \mathrm{h}\end{array}$ & $\begin{array}{c}\text { Bed } \\
\text { Weight, } \mathrm{g}\end{array}$ & $\begin{array}{c}\text { Bed } \\
\text { Size,cm } \\
\text { i.d. } \mathrm{xh}\end{array}$ & $\begin{array}{c}\text { Residence } \\
\text { Time, } \mathrm{s}\end{array}$ & $\mathrm{C}_{1}^{\mathrm{a}}, \mathrm{ug} / \mathrm{m}^{3}$ & $\mathrm{C}_{2}^{\mathrm{b}}, \mathrm{ug} / \mathrm{m}^{3}$ & \%RE \\
\hline 1 & Hgclvitbas1 & 29 & 1.03 & $1 \times 2.5$ & 0.53 & $943 \pm 22.0^{\mathrm{c}}$ & $6.71 \pm 0.260$ & $99.3 \pm 0.03$ \\
\hline 2 & Hgclvitbas2 & 16 & 0.260 & $1 \times 0.63$ & 0.14 & $803 \pm 75.0$ & $6.60 \pm 0.555$ & $99.2 \pm 0.10$ \\
\hline 3 & Hgclvitbt1 & 14 & 0.260 & $1 \times 0.63$ & 0.14 & $886 \pm 81.5$ & $3.84 \pm 0.244$ & $99.6 \pm 0.05$ \\
\hline 4 & Hgclvitbt3 & 14 & 0.263 & $1 \times 0.63$ & 0.14 & $774 \pm 14.0$ & $5.75 \pm 1.51$ & $99.3 \pm 0.20$ \\
\hline 5 & Hgvitbt1 & 16 & 0.199 & $1 \times 0.48$ & 0.10 & $494 \pm 14.0$ & $4.71 \pm 0.598$ & $99.1 \pm 0.12$ \\
\hline
\end{tabular}

a. Mean of measured mercury concentrations upstream of carbon bed

b. Mean of measured mercury concentrations downstream of carbon bed

c. One standard deviation

NOTES: 1. Flow rate through carbon bed: $220 \mathrm{cc} / \mathrm{min}$

2. Carbon bed temperature: $90^{\circ} \mathrm{C}$

3. Carbon particle size: $1-2 \mathrm{~mm}$

4. Run designations: bas = baseline gas composition, $46 \% \mathrm{H}_{2} \mathrm{O}, 45 \% \mathrm{~N}_{2}, 8.9 \% \mathrm{O}_{2}$

$\mathrm{bt}=$ simulated SBW vitrification off-gas (see Table 1)

$\mathrm{Hgcl}=\mathrm{HgCl}_{2} \quad \mathrm{Hg}=\mathrm{Hg}^{\mathrm{O}}$ 


\section{CONCLUSIONS AND RECOMMENDATIONS}

Mersorb ${ }^{\circledR}$, a sulfur-impregnated activated carbon, has the potential for removing mercury from SBW vitrification off-gas with a minimum mercury removal efficiency of $99 \%$. Since relatively low mercury concentrations were used in the tests, the maximum mercury removal efficiency could be much higher. Tests with a larger carbon bed to determine the maximum mercury removal efficiency under conditions more closely simulating full-scale operation should be conducted. Particularly, these tests should determine the effects of linear velocity and mercury concentration on removal efficiency and breakthrough capacity. The results of the scaled-up tests should be used to design a pilot-sized carbon adsorption bed for testing on a pilot-scale melter. The data obtained could be used to design a GAC bed of optimum size.

The components of the SBW vitrification off-gas should not have any short-term negative effects on mercury removal efficiency. As a conservative approach, the small bed tests should be continued to determine long-term effects of a simulated SBW vitrification off-gas on mercury removal efficiency. This could be accomplished by modifying the small bed test apparatus to operate unattended to enable 24hour operation. A 6-month test of long-term effects on mercury removal efficiency, compared to a baseline test gas composed of air and water vapor, should be conducted. 


\section{REFERENCES}

1. NWCF Calciner Emissions Inventory-Final Report for Test Series1,2 and 3, Part 2, Appendix C, INEEL/EXT-2000-001114, January 2000.

2. EPAweb site: http://www.epa.gov/epaoswer/hazwaste/combust/

3. Feasibility Study Report for NWCF MACT Compliance Facility, INEEL/INT-97-00992, November 1997.

4. NWCF Mercury Removal Feasibility Study, INEEL/INT-2000-00539, September 2000.

5. J. A. Del Debbio and L. G. Olson, letter to C. A. Musick, JAD-03-00/LGO-03-00, Final Report on the Use of Activated Carbon for Removal of Mercury from Simulated NWCF Off-Gas, dated September 28, 2000.

6. J. A. Del Debbio, L. G. Olson, T. L. Watson and L. G. Blackwood, Removal of Mercury from the Off-Gas from Thermal Treatment of Radioactive Liquid Wastes, Proceedings of the International Conference on Incineration and Thermal Treatment Technologies, May 14-18, Philadelphia, PA, available from the University of Maryland, Conference and Visitors Service, 0101 Annapolis Hall, College Park, MD 20742-9811. (301) 314-7884.

7. J. A. Del Debbio, L. G. Olson and J. H Pao, letter to S. C. Ashworth, JAD-02-00/LGO-02-00/ JHP-04-00, Final Report on Mercury Vapor/Liquid Equilibrium to Support Wet Scrubber Process Models for NWCF Upgrade, dated June 19, 2000.

8. D. D. Taylor, C. M. Barnes and L. Lauerhass, INEEL SBW Vitrification Process, INEEL/EXT-01-01139, September 2001.

9. K. J. Perry, R. R. Kimmitt, N. R. Soelberg, R. D. Tillotson and A. N. Olson, Test Results from SBW-FY01-PS-01 Vitrification Demonstration of Sodium-Bearing Waste Simulant Using WM180 Surrogate, INEEL/EXT-01-01073, August 2001.

10. J. J. Quigley, B. D. Raivo, S. O. Bates, S. M. Berry, D. N. Nishioka and P. J. Bunnell, Feasibility Study for Vitrification of Sodium-Bearing Waste, INEEL/EXT-2000-00952, September 2000.

11. H. W. Coleman and W. G. Steele, Experimentation and Uncertainty Analysis for Engineers, John Wiley and Sons, N. Y., 1989. 
Appendix A

Pictures of Test Apparatus 


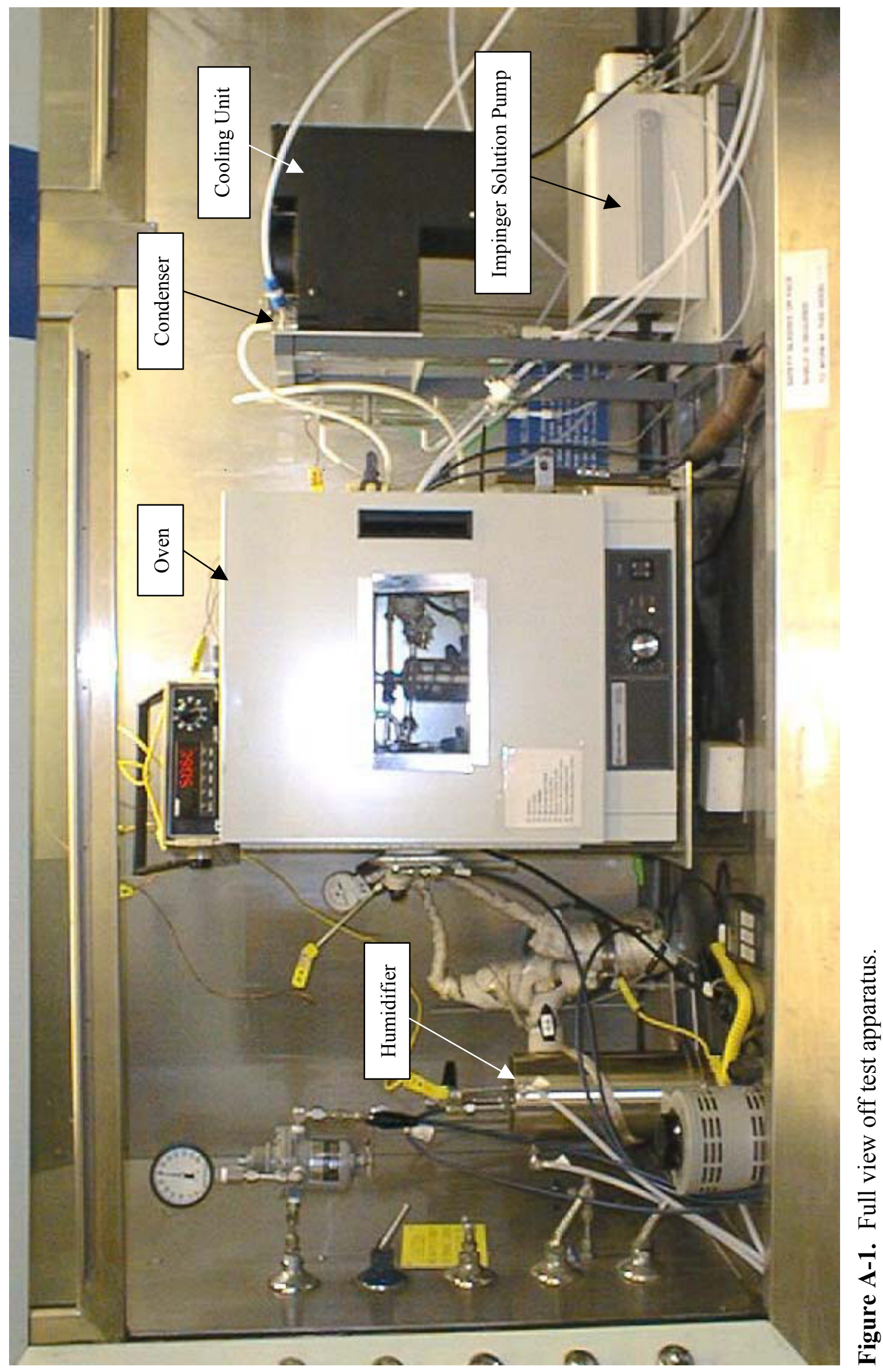




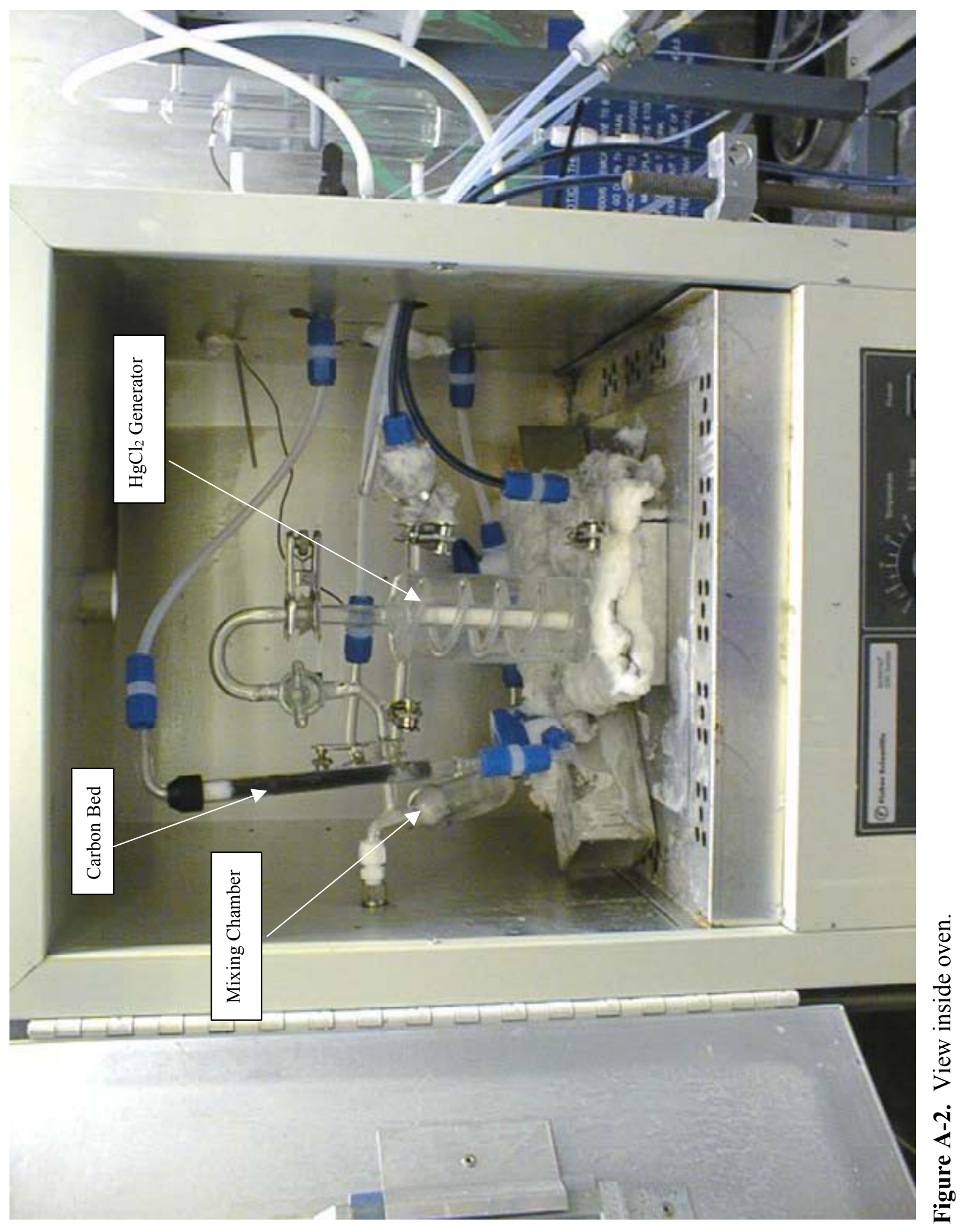




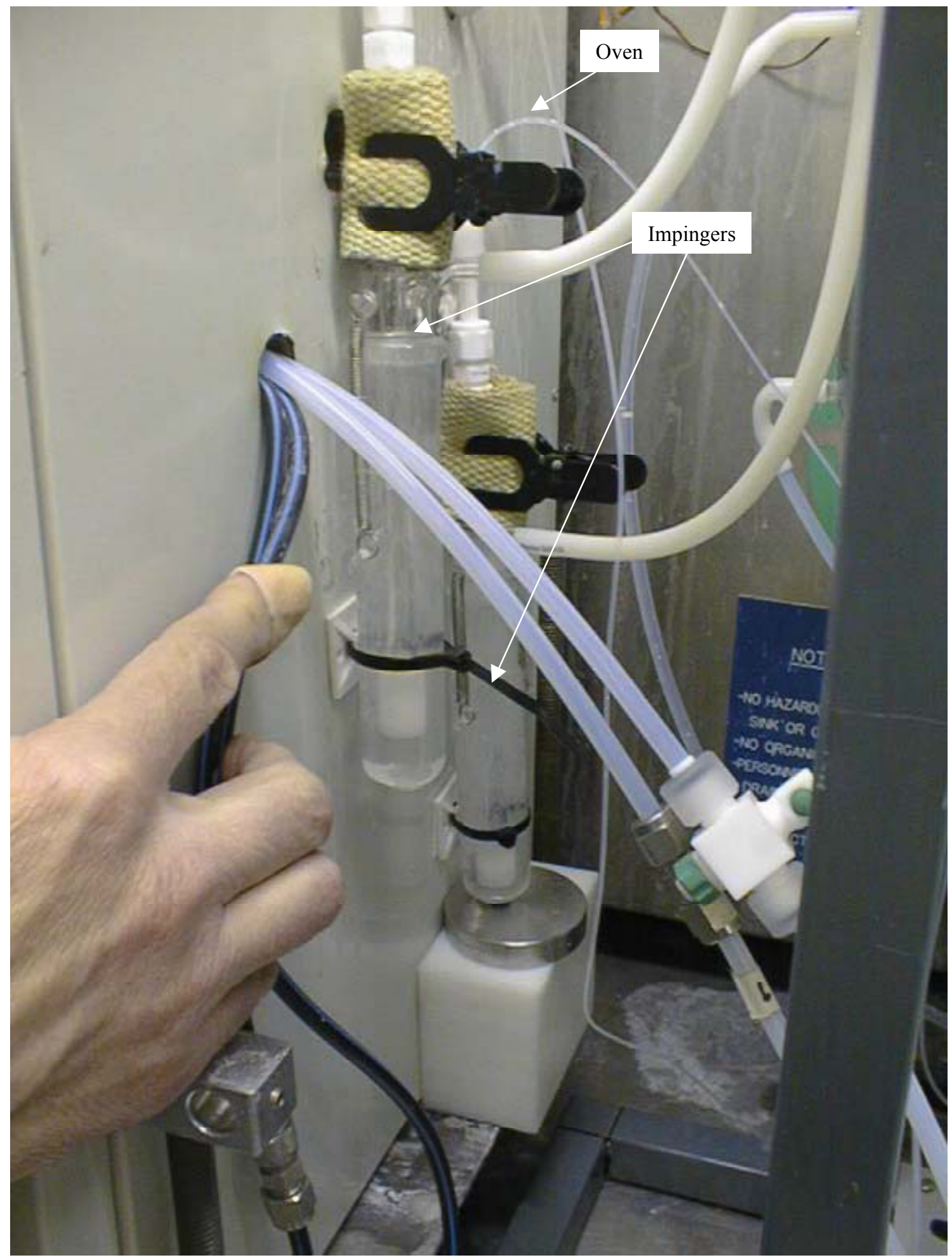

Figure A-3. View of impingers containing $\mathrm{SnCl}_{2} / \mathrm{NaOH}$ solution. 


\section{Appendix B \\ Derivation of Propagation of Error Equation}


where,

$\% \mathrm{RE}=$ Percent removal efficiency

$\mathrm{C}_{1}=$ Mean $\mathrm{HgCl}_{2}$ or $\mathrm{Hg}^{\mathrm{o}}$ concentration upstream of the carbon bed, $\mathrm{ug} / \mathrm{m}^{3}$

$\mathrm{C}_{2}=$ Mean $\mathrm{HgCl}_{2}$ or $\mathrm{Hg}^{\mathrm{o}}$ concentration downstream of the carbon bed, $\mathrm{ug} / \mathrm{m}^{3}$

Applying propagation of errors methods ${ }^{11}$ the standard deviation for the removal efficiency in Eq. 2 is estimated as:

$$
\begin{aligned}
& \sigma_{\% \mathrm{RE}}=\sqrt{\left(\frac{\partial \% \mathrm{RE}}{\partial \mathrm{C}_{1}}\right)^{2} \sigma_{\mathrm{C}_{1}}^{2}+\left(\frac{\partial \% \mathrm{RE}}{\partial \mathrm{C}_{2}}\right)^{2} \sigma_{\mathrm{C}_{2}}^{2}} \\
& \sigma_{\% \mathrm{RE}}=\sqrt{\left(\frac{100 \mathrm{C}_{2}}{\mathrm{C}_{1}^{2}}\right)^{2} \sigma_{\mathrm{C}_{1}}^{2}+\left(-\frac{100}{\mathrm{C}_{1}}\right)^{2} \sigma_{\mathrm{C}_{2}}^{2}} \\
& \sigma_{\% \mathrm{RE}}=100 \sqrt{\left(\frac{\mathrm{C}_{2}}{\mathrm{C}_{1}^{2}}\right)^{2} \sigma_{\mathrm{C}_{1}}^{2}+\left(\frac{1}{\mathrm{C}_{1}}\right)^{2} \sigma_{\mathrm{C}_{2}}^{2}}
\end{aligned}
$$

where the $\sigma$ values are the estimated standard deviations of the indicated terms and the $\partial$ symbols are the usual derivative calculations. 